\title{
KULTURISASI PENDIDIKAN KARAKTER DALAM PEMBELAJARAN DI SEKOLAH
}

\author{
Nanang Faisol Hadi, MSI \\ Guru PAI SMPN 5 Penajam Paser Utara Kalimantan Timur \\ Email: mulkeismatondang@yahoo.co.id
}

\begin{abstract}
Early childhood is a critical period for the establishment of a person's character. Many education experts say that the failure of character planting earlier can form personal problems in next adult life. Children will grow with characters if they grow up in an environment with character, so that the nature of every child born to develop optimally sacred. As the Prophet Muhammad said, which means: "Every child is born, must have been in a state of purity. Then both his parents who make it Jewish, Christian and Zoroastrian". (H.R. Imam Muslim). Character education requires as habit. Habituation to do good thing, to be honest, knight, to be shame cheated, lazy, and to let the environment dirty. Character is not formed instantly, but should be trained seriously and proportionate in order to achieve the ideal shape and strength.
\end{abstract}

Keywords: Education, Character, and Children.

\begin{abstract}
Abstrak
Usia dini merupakan masa kritis bagi pembentukan karakter seseorang. Banyak pakar pendidikan mengatakan bahwa kegagalan penanaman karakter sejak dini dapat membentuk pribadi yang bermasalah di masa dewasanya kelak. Anak-anak tumbuh menjadi pribadi berkarakter jika mereka tumbuh pada lingkungan yang berkarakter, sehingga fitrah setiap anak yang dilahirkan suci dapat berkembang secara optimal. Sebagaimana sabda Rasulullah SAW yang artinya: "Setiap anak yang dilahirkan, pasti dalam keadaan suci. Maka kedua orang tuanya lah yang menjadikannya yahudi, nasrani dan majusi". (H.R. Imam Muslim). Pendidikan karakter memerlukan pembiasaan. Pembiasaan untuk berbuat baik, pembiasaan untuk berlaku jujur, ksatria, malu berbuat curang, malu bersikap malas, malu membiarkan lingkungannya kotor. Karakter tidak terbentuk secara instan, tapi harus dilatih secara serius dan proporsional agar mencapai bentuk dan kekuatan yang ideal.
\end{abstract}

Kata Kunci: Pendidikan, Karakter, and Anak-anak.

\section{PENDAHULUAN}

Penguatan pendidikan moral (moral education) ${ }^{1}$ atau pendidikan karakter (character education $)^{2}$ dalam konteks sekarang sangat relevan untuk mengatasi krisis moral yang

\footnotetext{
${ }^{1}$ Moral, karakter dan akhlak memiliki perbedaan. Moral adalah pengetahuan seseorang terhadap hal baik dan buruk yang ada dan melekat dalam diri seseorang. Istilah moral berasal dari bahasa Latin mores dari suku kata mos, yang artinya adat istiadat, kelakuan tabiat, watak. Moral merupakan konsep yang berbeda. Moral adalah prinsip baik buruk sedangkan moralitas merupakan kualitas pertimbangan baik buruk. Moral pendidikan adalah nilai-nilai yang terkandung secara built in dalam setiap bahan ajar atau ilmu pengetahuan. Akhlak (bahasa
} 
sedang melanda di negara kita. Krisis tersebut antara lain berupa meningkatnya pergaulan bebas, maraknya angka kekerasan anak-anak dan remaja, kejahatan terhadap teman, pencurian remaja, kebiasaan menyontek, penyalahgunaan obat-obatan, pornografi, dan perusakan milik orang lain sudah menjadi masalah sosial yang hingga saat ini belum dapat diatasi secara tuntas.

Krisis yang melanda pelajar (juga elite politik) mengindikasikan bahwa pendidikan agama dan moral yang didapat di bangku sekolah (kuliah) tidak berdampak terhadap perubahan perilaku manusia Indonesia. Bahkan yang terlihat adalah begitu banyak manusia Indonesia yang tidak koheren antara ucapan dan tindakannya. Kondisi demikian, diduga berawal dari apa yang dihasilkan oleh dunia pendidikan. ${ }^{3}$

Demoralisasi tejadi karena proses pembelajaran cenderung mengajarkan pendidikan moral dan budi pekerti sebatas teks dan kurang mempersiapkan siswa untuk menyikapi dan menghadapi kehidupan yang kontradiktif. Dalam konteks pendidikan formal di sekolah/madrasah, bisa jadi salah satu penyebabnya karena pendidikan di Indonesia lebih menitik beratkan kepada pengembangan intelektual atau kognitif semata, sedangkan aspek soft skill atau nonakademik sebagai unsur utama pendidikan moral belum diperhatikan.

Padahal, pencapaian hasil belajar siswa tidak dapat hanya dilihat dari ranah kognitif dan psikomotorik, sebagaimana selama ini terjadi dalam praktik pendidikan kita, tetapi harus juga dilihat dari hasil afektif, Ketiga ranah berhubungan secara resiprokal, meskipun kekuatan hubungannya bervariasi dari satu kasus ke kasus yang lain. Beberapa hasil penelitian menunjukkan bahwa efektivitas pencapaian hasil kognitif terjadi sejalan dengan efektivitas pencapaian ranah afektif. ${ }^{4}$

Pemerintah telah mencanangkan visi penerapan pendidikan karakter, maka diperlukan kerja keras semua pihak, terutama terhadap program-program yang memiliki kontribusi besar terhadap peradaban bangsa harus benar-benar dioptimalkan. Namun, penerapan pendidikan karakter di sekolah/ madrasah memerlukan pemahaman tentang konsep, teori, metodologi dan aplikasi yang relevan dengan pembentukan karakter (character building) dan pendidikan karakter (character education).

Pendidikan karakter telah menjadi perhatian berbagai negara dalam rangka mempersiapkan generasi yang berkualitas, bukan hanya untuk kepentingan individu warga negara, tetapi juga untuk warga masyarakat secara keseluruhan. Pendidikan karakter dapat diartikan sebagai the deliberate us of all dimensions of school life to foster optimal character

Arab), bentuk plural dari khuluq adalah sifat manusia yang terdidik. Baca Muhammad al-Abd, t.t., al-khlāq fi alIslām, (Cairo: al-Jami'ah al-Qahirah, t.t.), hln. 11.

${ }^{2}$ Karakter adalah tabiat seseorang yang lansung di-drive oleh otak. Munculnya tawaran istilah pendidikan karakter (character education) merupakan kritik dan kekecewaan terhadap praktik pendidikan moral selama ini. Walaupun secara substansial, keduanya tidak memiliki perbedaan yang prinsipiil.

${ }^{3} Z$ ubaidi, 2011. Desain Pendidikan Karakter, (Jakarta: Prenada Media Group, 2011), hlm. 2.

${ }^{4}$ Hadjar, "Evaluasi Hasil Belajar Afektif Pendidikan Agama: Konsep dan Pengukurannya”, Muntholi'ah (ed.), Guru Besar Bicara Mengembangkan Keilmuan Pendidikan Islam, (Semarang: Fakultas Tarbiyah IAIN Walisanga dan RaSAIL Media Group, 2010), hlm. 215. 
development (usaha kita secara sengaja dari seluruh dimensi kehidupan sekolah/madrasah untuk membantu pembentukan karakter secara optimal.

Menurut Lickona, karakter berkaitan dengan konsep moral (moral knonwing), sikap moral (moral felling), dan perilaku moral (moral behavior). ${ }^{5}$ Berdasarkan ketiga komponen ini dapat dinyatakanbahwa karakter yang baikdidukung oleh pengetahuan tentang kebaikan, keinginan untuk berbuat baik, dan melakukan perbuatan kebaikan. Bagan dibawah ini merupakan bagan kerkaitanketiga kerangka pikir ini.

Berdasarkan tujuan pendidikan nasional, maka pendiikan karakter adalah suatu program pendidikan (sekolah dan luar dekolah) yang mengorganisasikan dan menyederhanakan sumber-sumber moral dan disajikan dengan memerhatikan pertimbangan psikologis untuk pertimbangan pendidikan.

Tujuan pendidikan karakter adalah mengajarkan nilai-nilai tradisional tertentu, nilainilai yang diterima secara luas sebagai landasan perilaku yang baik dan bertanggung jawab. Nilai-nilai ini juga digambarkan sebagai perilaku moral. ${ }^{6}$ Pendidikan karakter selama ini baru dilaksanakan pada jenjang pendidikan pra sekolah/madrasah (taman kanak-kanak atau raudhatul athfäl). Sementara pada jenjang sekolah dasar dan seterusnya kurikulum di Indonesia masih belum optimal dalam menyentuh aspek karakter ini, meskipun sudah ada materi pelajaran Pancasila dan Kewarganegaraan. Padahal jika Indonesia ingin memperbaiki mutu sumber daya manusia dan segera bangkit dari ketinggalannya, maka Indonesia harus merombak sistem pendidikan yang ada, antara lain memperkuat pendidikan karakter.

Strategi pembelajaran yang berkenaan dengan moral knowingakan lebih banyak belajar melalui sumber belajar dan nara sumber. Pembelajaran moral lovingakan terjadi pola saling membelajarkan secara seimbang di antara siswa. Sedangkan pembelajaran moral doingakan lebih banyak menggunakan pendekatan individual melalui pendampingan pemanfaatan potensi dan peluang yang sesuai dengan kondisi lingkungan siswa. Ketiga strategi pembelajaran tersebut sebaiknya dirancang secara sistematis agar para siswa dan guru dapat memanfaatkan segenap nilai-nilai dan moral yang sesuai dengan potensi dan peluang yang tersedia di lingkungannya.

Dengan demikian, hasil pembelajarannya ialah terbentuknya kebiasaan berpikir dalam arti peserta didik memiliki pengetahuan, kemauan dan keterampilan dalam berbuat kebaikan. Melalui pemahaman yang komprehensif ini diharapkan dapat menyiapkan polapola manajemen pembelajaran yang dapat menghasilkan anak didik yang memiliki karakter yang kuat dalam arti memiliki ketangguhan dalam keilmuan, keimanan, dan perilaku shaleh, baik secara pribadi maupun sosial.

${ }^{5}$ Zubaedi, Desain...., hlm. 29.

${ }^{6}$ Zuchdi, Humanisasi Pendidikan, (Jakarta: PT Bumi Aksara, 2009), hlm. 39 


\section{PEMBAHASAN}

\section{Pendidikan kekinian}

Barangkali tidak banyak yang menyadari bahwa sistem pendidikan di Indonesia dominan hanya menyiapkan para siswa untuk masuk ke jenjang perguruan tinggi atau hanya untuk mereka yang memang mempunyai bakat pada potensi akademik (ukuran IQ tinggi) saja. Hal ini terlihat dari bobot mata pelajaran yang diarahkan kepada pengembangan dimensi akademik siswa yang sering hanya diukur dengan kemampuan logika-matematika dan abstraksi (kemampuan bahasa, menghafal, abstraksi atau ukuran IQ). ${ }^{7}$ Bersamaan dengan itu, banyak lahir praksis pendidikan yang cenderung memperlakukan peserta didik dan juga guru sebagai robot, inhuman, dan impersonal. Hasil akhirnya berupa lulusan institusi pendidikan dengan karakteristik dasar pribadi yang tidak kreatif dan lemah kemandiriannya. ${ }^{8}$

Memang beberapa siswa Indonesia bisa berprestasi mendapatkan hadiah olimpiade. Namun dapat dipastikan bahwa mereka adalah bagian dari top 0.1 persen tingkat IQ tertinggi saja (bukan cerminan dari kondisi seluruh siswa Indonesia). Sudah puluhan tahun energi bangsa kita terbuang sia-sia untuk menciptakan manusia Indonesia yang menguasai IPTEK dengan segala beban kurikulum yang luar biasa beratnya.

Metode pembelajaran di kelas banyak yang menyalahi teori-teori perkembangan anak. Hasilnya adalah generasi yang tidak percaya diri (apalagi kalau divonis dengan sistem ranking di sekolah), sehingga sempurnalah pencetakan SDM Indonesia yang berada di urutan terbawah; tidak bisa bekerja, tidak terampil, tidak percaya diri, dan tidak berkarakter. Mereka tumbuh dikondisikan oleh sebuah sistem yang salah. ${ }^{9}$

Selain itu, karena tujuan pendidikan diarahkan untuk mencetak anak pandai secara kognitif (yang menekankan pengembangan otak kiri saja dan hanya meliputi aspek bahasa dan logis-matematis), maka banyak materi pelajaran yang berkaitan dengan pengembangan otak kanan (seperti kesenian, musik, imajinasi, dan khususnya pembentukan karakter) kurang mendapatkan perhatian. Kalaupun ada, maka orientasinya pun lebih kepada kognitif (hafalan), tidak ada apresiasi dan penghayatan yang dapat menumbuhkan kegairahan untuk belajar dan mendalami materi lebih lanjut. Celakanya, pendekatan yang terlalu kognitif telah mengubah orientasi belajar para siswa menjadi semata-mata untuk meraih nilai tinggi.

Hal ini dapat mendorong para siswa untuk mengejar nilai dengan cara yang tidak jujur, seperti mencontek, menjiplak, dan sebagainya. Mata pelajaran yang bersifat subject matter juga makin merumitkan permasalahan karena para siswa tidak melihat bagaimana keterkaitan antara satu mata pelajaran dengan yang lainnya, serta tidak relevan dengan kehidupan nyata. Akibatnya para siswa tidak mengerti manfaat dari materi yang dipelajarinya untuk kehidupan nyata.

\footnotetext{
${ }^{7}$ Akhmad Muhaimin Azzet, Urgensi...hlm. 94

${ }^{8}$ Sudarwan Danim. 2003. Agenda Pembaruan Sistem Pendidikan. Yogyakarta: Pustaka Pelajar, hlm. 143-144.

${ }_{9}^{9}$ Syaiful Sagala, Pendidikan Kontemporer, (Jakarta, Alfabeta, 2009), hlm. 83
} 
Sistem pendidikan seperti ini membuat manusia berpikir secara parsial, terkotakkotak. Isu-isu terbesar saat ini pasti berakar dari kegagalan kita untuk melihat segala sesuatu secara keseluruhan. Kegagalan tersebut terjadi ketika kita terbiasa berpikir secara terkotakkotak dan tidak diajarkan bagaimana untuk berpikir secara keseluruhan dalam melihat keterkaitan antar kotak-kotak tersebut, atau untuk mempertanyakan bagaimana suatu kotak (perspektif) dapat terkait dengan kotak-kotak lainnya. ${ }^{10}$

Apabila dalam dunia fisika paradigma telah bergeser dari pendekatan mekanistik dan terfragmentasi dalam menelaah partikel-partikel benda mati ke arah pendekatan menyeluruh, maka sudah seharusnya pendekatan yang sama diterapkan dalam bidangbidang keilmuan lainnya, terutama yang menyangkut bagaimana mempelajari manusia dan semua unsur-unsur peradabannya. ${ }^{11}$ Oleh karena itu, perlu dilaksanakan reorientasi pendidikan ke arah yang lebih kondusif untuk terciptanya kualitas SDM yang berkualitas, terutama melalui pengenalan konsep pendidikan karakter menyeluruh (integratif caracter holistic).

Manusia yang terdidik seharusnya menjadi orang bijak, yaitu yang dapat menggunakan ilmunya untuk hal-hal yang baik (beramal shaleh), dan dapat hidup secara bijak dalam seluruh aspek kehidupan berkeluarga, bertetangga, bermasyarakat, dan bernegara. ${ }^{12}$

Karenanya, sebuah sistem pendidikan yang berhasil adalah yang dapat membentuk manusia-manusia berkarakter yang sangat diperlukan dalam mewujudkan sebuah negara yang terhormat. Kurikulum integratif holistic berbasis karakter, yang merupakan kurikulum terpadu yang "menyentuh" semua aspek kebutuhan anak. Sebuah kurikulum yang terkait, tidak terkotak-kotak dan dapat merefleksikan dimensi, keterampilan, dengan menampilkan tema-tema yang menarik dan kontekstual.

Pembelajaran integratif caracter holistic terjadi apabila kurikulum dapat menampilkan tema yang mendorong terjadinya eksplorasi atau kejadian-kejadian secara autentik dan alamiah. Dengan munculnya tema atau kejadian yang alami ini akan terjadi suatu proses pembelajaran yang bermakna dan materi yang dirancang akan saling terkait dengan berbagai bidang pengembangan yang ada dalam kurikulum.

Pembelajaran integratif caracter holistic berlandaskan pada pendekatan inquiry dimana anak dilibatkan dalam merencanakan, bereksplorasi dan berbagi gagasan. Anakanak didorong untuk berkolaborasi bersama teman-temannya dan belajar dengan "cara"

${ }^{10}$ Muhaimin, dkk, Paradigma Pendidikan Islam, (Bandung, Rosda Karya, 2008), hlm. 89

${ }^{11}$ Widiastono, Tony D. (ed). 2004. Pendidikan Manusia Indonesia...Op.Cit. hlm. 9.

12 Ardian Husaini, Pendidikan Islam: Membentuk Manusia Berkarakter dan Beradab, (Jakarta, Cakrawala Publishing, 2010), hlm. 90 
mereka sendiri untuk belajar. ${ }^{13}$ Anak-anak diberdayakan sebagai si pembelajar dan mampu mengejar kebutuhan belajar mereka melalui tema-tema yang dirancang. ${ }^{14}$

Sebuah pembelajaran yang integratif caracter holistic hanya dapat dilakukan dengan baik apabila pembelajaran yang dilakukan alami, natural, nyata, dan dekat dengan diri anak.Guru-guru yang melaksanakannya memiliki pemahaman konsep pembelajaran terpadu dengan baik. Selain itu juga dibutuhkan kreativitas dan bahan-bahan/sumber yang kaya serta pengalaman guru dalam berlatih membuat model-model yang tematis juga sangat menentukan kebermaknaan pembelajaran. Intinya semua yang berkaitan dengan pembelajaran harus memiliki karakter.

Agenda mengembalikan orientasi dan dasar pendidikan sebagai tata laksana penyelenggaraan pendidikan harus mengacu pada tujuan bangsa dan cita-cita nasional. ${ }^{15}$ Terutama sebagai landasan filosofi (way of life), idiologi, weltanschauung (nilai dasar) maupun worldview masyarakatnya yang diyakini memiliki kebenaran yang telah teruji oleh sejarah. Hal ini dimaksudkan agar visi pendidikan ke depan tidak mudah diombang-ambingkan oleh kepentingan, tuntutan, dan isu-isu sesaat, yang pada gilirannya terjebak pada pemikiran jangka pendek.

Oleh sebab itu, jika ingin menjadi perubah peradaban bangsa yang dilingkupi peradaban yang tidak sehat ini, tidak bisa tidak, usaha pendidikan harus mengalami rekonstruksi secara mendasar khususnya di bidang kurikulum. Sehingga, diperlukan reorientasi visi dan paradigma pendidikan yang mengarah pada upaya rekonstruksinya. Cara pandang ini mengimplikasikan perubahan paradigma pendidikan dengan mengacu pada landasan filosofi dan framework yang jelas dan terarah.

Meskipun bukan satu-satunya faktor penentu, tetapi setidaknya paradigma yang berasal dari penggalian, elaborasi dan penjabaran, serta penerapan ini pada gilirannya dapat digunakan sebagai dasar dan paradigma pendidikan Indonesia. ${ }^{16}$

13 Dede Rosyada. 2004. Paradigma Pendidikan Demokratis: Sebuah Model Pelibatan Masyarakat dalam Penyelenggaraan Pendidikan. Jakarta: Kencana, cet. I, hlm. 91.

${ }^{14}$ Agus Irianto, Pendidikan Sebagai Investasi dalam Pembangunan Bangsa, (Jakarta, Kencana Prenada Media, 2011), hlm. 103

${ }^{15}$ Dalam fungsinya sebagai penjaga dan penanam nilai-nilai, S. Parvez Manzoor mengemukakan bahwa filsafat pendidikan tidak hanya membentuk identitas dan tujuan akhir sebuah komunitas, tapi juga merupakan basis yang paling dasar dari semua kebudayaan dan peradaban (Lihat: Ziauddin Sardar. 2000. Merombak Pola Pikir Intelektual Muslim. (terj.) Agung Prihantoro dan Fuad Arif Fudyartanto. Yogyakarta: Pustaka Pelajar, hlm. 95).

16 Menurut Anita Lie, petunjuk atau paradigma merupakan suatu teori, perspektif, atau kerangka berpikir yang menentukan bagaimana kita memandang, menginterpretasikan, dan memahami aspek-aspek kehidupan, sehingga bisa dikatakan sebagai peta perjalanan kita dalam kehidupan ini. Dalam hlm. ini, Lie mengetengahkan ilustrasi menarik. Ibaratnya, kita ingin bepergian menuju kota tertentu, tapi tanpa sadar memakai peta ke arah yang bukan menjadi tujuan awal kita. Tentu saja, sebaik-baik usaha kita selama di perjalanan, kita tidak akan mencapai tujuan tersebut secara benar. Padahlm. untuk bisa mencapai tujuan dengan benar membutuhkan peta yang baik dan tepat. Permasalahan pokoknya bukan terletak pada tindakan atau usaha kita, namun terletak pada petunjuk atau peta yang salah. Jika tetap berpegang pada peta itu, pastilah semua usaha yang dilakukan akan siasia. Menurut Lie, petunjuk atau paradigma itu merupakan suatu teori, perspektif, atau kerangka berpikir yang menentukan bagaimana kita memandang, menginterpretasikan, dan memahami aspek-aspek kehidupan, 
Sesuai dengan jalan pikiran dan identifikasi masalah sebagaimana dipaparkan terdahulu, tampak jelas bahwa realitas pendidikan di Indonesia kini membutuhkan rekonseptualisasi, peninjauan ulang, serta rekonstruksi terhadap landasan dasar dan penerapan kurikulumnya guna mengeksplisitkan visi dan arah (direction) pembangunan bangsa. Itulah sebabnya, langkah dan rencana strategis (renstra) yang mesti kita tempuh adalah mengembalikan "keberdayaan" pendidikan dalam menyiapkan pribadi dan individu yang cerdas, terampil, bertanggung jawab (berkarakter) secara moral dan agamis, ber-akhlaq al-karim, serta berperadaban rahmatan li-'alamin sebagai manifestasi insan kamil.

Terlepas dari berbagai kekurangan dalam praktik pendidikan di Indonesia, apabila dilihat dari standar nasional pendidikan yang menjadi acuan pengembangan kurikulum, dan implementasi pembelajaran dan penilaian di sekolah, tujuan pendidikan sebenarnya dapat dicapai dengan baik. Pembinaan karakter juga termasuk dalam materi yang harus diajarkan dan dikuasai serta direalisasikan oleh peserta didik dalam kehidupan sehari-hari.

Permasalahannya, pendidikan karakter di sekolah selama ini baru menyentuh pada tingkatan pengenalan norma atau nilai-nilai, dan belum pada tingkatan internalisasi dan tindakan nyata dalam kehidupan sehari-hari.Pendidikan karakter seharusnya membawa peserta didik ke pengenalan nilai secara kognitif, penghayatan nilai secara afektif, dan akhirnya ke pengamalan nilai secara nyata. Permasalahan pendidikan karakter yang selama ini ada perlu segera dikaji, dan dicari altenatif-alternatif solusinya, serta perlu dikembangkannya secara lebih operasional sehingga mudah diimplementasikan di sekolah.

\section{Konsep Kurikulum}

Secara etimologi, kurikulum berasal dari bahasa Yunani, yaitu curir yang artinya berlari dan curere yang berarti tempat berpacu. ${ }^{17}$ Dalam bahasa Latin, kurikulum berasal dari kata curriculum yang berarti a running course, or race course, especially a charioy race course. Sedangkan dalam bahasa Prancis, kurikulum dikaitkan dengan kata courier yang artinya to run, berlari. Kemudian, istilah itu digunakan untuk sejumlah courses atau mata pelajaran yang harus ditempuh guna mencapai suatu gelar atau ijazah. ${ }^{18}$

Dalam UU Sisdiknas No.20 Tahun 2003, kurikulum didefinisikan sebagai seperangkat rencana dan pengaturan mengenai tujuan, isi, dan bahan pelajaran serta cara yang digunakan sebagai pedoman dalam penyususnan kurikulum tingkat satuan pendidikan.

Sementara, S. Nasution yang mengutip pendapat Saylor dan Alexander mengatakan, kurikulum merupakan the total effort the school to going about desired outcomes in school and out-

sehingga bisa dikatakan sebagai peta perjalanan kita dalam kehidupan ini (Lihat: Anita Lie. 2002. Cooperative Learning: Mempraktikkan Cooperative Learning di Ruang-Ruang Kelas. Jakarta: Grasindo, cet. I, hlm. 1-2).

${ }_{17}$ Abdullah Idi, Pengembangan kurikulum; Teori dan Praktik, (Ar Ruzz Media, Yogyakarta, 2007). Hlm. 183

${ }^{18}$ S. Nasution, Pengembangan Kurikulum, (Citra Aditya Bakti, Bandung, 2003). Hlm. 9 
of-school situations. ${ }^{19}$ Dari pernyataan tersebut, Saylor dan Alexander memaknai kurikulum sebagai usaha total sekolah untuk mencapai tujuan yang diinginkan, baik didalam maupun diluar sekolah.

Selain itu, ada definisi kurikulum yang lebih popular, yakni all the experiences that pupils have under the guidance of the school, segala pengalaman yang dimiliki peserta didik dibawah bimbingan sekolah. ${ }^{20}$ Dalam hal ini, berarti sekolah telah merumuskan berbagai kegiatan pembelajaran, baik didalam maupun diluar sekolah, untuk memberikan pengalaman belajar bagi anak.

Pengalaman peserta didik yang tidak direncanakan oleh sekolah/guru disebut kurikulum tersembunyi (hidden curriculum). Menurut Abdullah Idi, hidden curriculum tidak direncanakan oleh sekolah dalam programnya dan tidak ditulis atau dibicarakan oleh guru. Sehingga, kurikulum ini merupakan upaya murni peserta didik atas potensi dan kreativitas mereka yang tentunya bias berkonotasi positif, hidden curriculum member manfaat bagi individu peserta didik, guru, dan sekolah. Misalnya, peserta didik ingin menjadi juara kelas melalui teknik nelajar yang dimiliki. Sebaliknya, dalam konotasi negative, keberadaan hidden curriculum ini tidak menguntungakan bagi peserta didik, guru, kepala sekolah, maupun orang tua. Misalnya, peserta didik ingin menjadi juara kelas dengan cara menyontek. ${ }^{21}$

Adapun menurut Oemar Hamalik, kurikulum adalah program pendidikan yang disediakan oleh lembaga pendidikan (sekolah) bagi peserta didik. Berdasarkan program pendidikan tersebut, peserta didik melakukan berbagai kegiatan belajar, sehingga mampu mendorong perkembangan dan pertumbuhan mereka sesuai dengan tujuan pendidikan yang telah ditetapkan. Kurikulum tidak terbatas pada sejumlah mata pelajaran, namun meliputi segala sesuatu yang dapat mempengaruhi perkembangan peserta didik, seperti bangunan sekolah, alat pelajaran, perlengkapan sekolah, pepustakaan, karyawan tata usaha, gambar-gambar, halaman sekolah, dan lain-lain.

Curriculum is interpreted to mean all of the organized courses activities, and experience which pupils have under the direction of school, whether in the classroom or not. ${ }^{22}$ Itulah yang dikemukakan oleh Oemar Hamalik. Berdasarkan rumusan tersebut, kegiatan kurikuler tidak hanya terbatas di dalam ruangan kelas, tetapi juga mencakup kegiatan didalam ruangan kelas, tetapi juga mencakup kegiatan diluar kelas. Definisi kurikulum tersebut dapat dijadikan pijakan bagi para pendidik untuk melakukan kegiatan pembelajaran bukan hanya di dalam kelas tetapi juga diluar kelas, misalnya put bond, outdoor class/ outing class dengan diselingi pelbagai games atau puzzles, study tour, dan lain-lain.

\footnotetext{
${ }^{19}$ Ibid., hlm. 10

${ }^{20}$ Ibid., hlm. 10

${ }^{21}$ Abdullah Idi, Pengembangan...... hlm. 50-51

${ }^{22}$ Oemar Hamalik, Manajemen Pengembangan Kurikulum, (Rosdakarya, Bandung, 2007). hlm. 10
} 
Jadi, kurikulum merupakan rencana tertulis yang berisi tentang ide-ide dan gagasangagasan yang dirumuskan oleh pengembang kurikulum. Kurikulum dapat diartikan sebagai sebuah dokumen perencanaan yang berisi tujuan yang harus dicapai, isi materi dan pengalaman belajar yang harus dilakukan peserta didik, strategi dan cara yang dapat dikembangkan, evaluasi yang dirancang untuk mengumpulkan informasi tentang pencapaian tujuan, serta implementasi dari dokumen yang dirancang dalam kehidupan nyata. Komponen-komponen kurikulum saling berkaitan dan saling mempengaruhi, terdiri dari tujuan yang menjadi arah pendidikan, komponen pengalaman belajar, komponen strategi pencapaian tujuan, dan komponen evaluasi. ${ }^{23}$ Kurikulum berfungsi sebagai pedoman yang memberikan arah dan tujuan pendidikan.

Di era kurikulum 2004-2008 yang menggunakan kurikulum KBK dan KTSP, pembelajaran lebih mendapatkan penegasan pada kewenangan guru untuk menentukan indikator, pengalaman belajar, dan rangkaian belajar yang bisa mengantarkan tercapainya Kompetensi Dasar dan Standar Kompetensi yang sudah dibuat oleh pemerintah pusat. Bahkan untuk pendidikan agama (PAI) dan pendidikan kewarganegaraan sudah mendapatkan pembobotan yang jelas, yakni PAI dengan akhlak mulia atau budi pekerti dan PPKN terkonsentrasi pada kepribadian.

Kalau saja mata pelajaran ini bisa diturunkan dalam pembelajaran nyata di sekolah/madrasah, dengan fokus dan pendekatan yang jelas pada akhlak mulia, budi pekerti, dan kepribadian, seharusnya sudah bisa memberi harapan yang jauh lebih baik untuk memperbaiki akhlak siswa dibanding dengan harapan pada kurikulum sebelumnya. Namun untuk melakukan penguatan bagi perubahan perilaku peserta didik yang semakin berakhlak yang mengarah pada perolehan nilai-nilai hidup, bukan semata-mata nilai angka yang hanya menggambarkan prestasi akademik, bukan belajar untuk berprestasi dalam kehidupan.

Menurut Audrey dan Howard Nichools, rekonstruksi kurikulum adalah the planning of learning opportunities intended to bring about certain desired in pupils, and assessment of the extend to which these changes have taken place. ${ }^{24}$ Artinya pengembangan kurikulum adalah perencanaan kesempatan-kesempatan belajar yang dimaksudkan untuk membawa peserta didik kearah perubahan-perubahan yang di inginkan serta menilai hingga sejauh mana perubahan-perubahan itu yang telah terjadi pada diri peserta didik. Adapun yang dimaksud kesempatan belajar (learning opportunity) adalah hubungan yang telah direncanakan dan terkontrol antara para peserta didik, guru, bahan dan peralatan, serta lingkungan belajar. Semua kesempatan belajar yang direncanakan oleh guru bagi para peserta didik sesungguhnya adalah "kurikulum itu sendiri". ${ }^{25}$

${ }^{23}$ Sanjaya, Kurikulum dan Pembelajaran, (Jakarta: Kencana Prenda Media Group, 2010), hlm. 16

${ }^{24}$ Oemar Hamalik, Manajemen Pengembangan Kurikulum, (Bandung: Remaja Rosdakarya, 2007), hlm. 96.

${ }^{25} \mathrm{Ibid}, \mathrm{hlm} .97$ 
Berdasarkan pengertian tersebut, rekonstruksi kurikulum sesungguhnya adalah sebuah siklus, suatu proses berulang yang tidak pernah berakhir. Proses kurikulum itu sendiri terdiri atas empat unsur. Pertama, tujuan, yakni mempelajari serta menggembarkan semua sumber pengetahuan dan pertimbangan tentang tujuan-tujuan pengajaran, baik yang berkenan dengan mata pelajaran (subject course) maupun kurikulum secarah menyeluruh. Kedua, metode dan material, yakni mengembangkan serta mencoba menggunakan metode dan material sekolah untuk mencapai tujuan-tujuan yang serasi menurut pertimbangan guru. Ketiga, penilaian (assessment), yakni menilai keberhasilan pekerjaan yang telah dikembangkan dalam kaitan dengan tujuan yang telah ditetapkan sebelumnya atau mengembangkan tujuan-tujuan baru. Keempat, feedbeck, yakni umpan balik dari semua pengalaman yang telah diperoleh, yang pada gilirannya menjadi titik bagi studi selanjutnya. ${ }^{26}$

\section{Pendidikan Karakter}

Secara etimologis, kata karakter bisa berarti tabiat, sifat-sifat kejiwaan, akhlak atau budi pekerti yang membedakan seseorang dengan yang lain, atau watak. ${ }^{27}$ Orang berkarakter berarti orang yang memiliki watak, kepribadian, budi pekerti, atau akhlak. Dengan makna seperti ini berarti karakter identik dengan kepribadian atau akhlak. Kepribadian merupakan ciri atau karakteristik atau sifat khas dari diri seseorang yang bersumber dari bentukan-bentukan yang diterima dari lingkungan, misalnya keluarga pada masa kecil, dan juga bawaan sejak lahir. ${ }^{28}$

Secara terminologis, makna karakter dikemukakan oleh Thomas Lickona. Menurutnya karakter adalah "A reliable inner disposition to respond to situations in a morally good way." Selanjutnya ia menambahkan, "Character so conceived has three interrelated parts: moral knowing, moral feeling, and moral behavior". ${ }^{29}$ Menurut Lickona, karakter mulia (good character) meliputi pengetahuan tentang kebaikan, lalu menimbulkan komitmen (niat) terhadap kebaikan, dan akhirnya benar4 benar melakukan kebaikan. Dengan kata lain, karakter mengacu kepada serangkaian pengetahuan (cognitives), sikap (attitides), dan motivasi (motivations), serta perilaku (behaviors) dan keterampilan (skills).

Dari pengertian di atas dapat dipahami bahwa karakter identik dengan akhlak, sehingga karakter merupakan nilai-nilai perilaku manusia yang universal yang meliputi seluruh aktivitas manusia, baik dalam rangka berhubungan dengan Tuhannya, dengan

${ }^{26}$ Ibid, hlm. 97

27 Tim Redaksi Tessaurus Bahasa Indonesia. Tesaurus Bahasa Indonesia Pusat Bahasa. (Departemen Pendidikan Nasional, Jakarta, 2008). hlm. 229

${ }^{28}$ Doni Koesoema A. Pendidikan Karakter; Strategi Mendidik Anak Di Zaman Global. (Grasindo, Jakarta, 2007). hlm. 80

29 Thomas Lickona. Educating for Character: How Our School Can Teach Respect and Responsibility. (Bantam books, (New York, Toronto, London, Sydney, Aucland), 1991). hlm. 51 
dirinya, dengan sesama manusia, maupun dengan lingkungannya, yang terwujud dalam pikiran, sikap, perasaan, perkataan, dan perbuatan berdasarkan norma-norma Agama, hokum, tata karma, budaya, dan adat istiadat. Dari konsep karakter ini muncul konsep pendidikan karakter (character education).

Karakter merupakan nilai-nilai perilaku manusia yang berhubungan dengan Tuhan Yang Maha Esa, diri sendiri, sesama manusia, lingkungan, dan kebangsaan yang terwujud dalam pikiran, sikap, perasaan, perkataan, dan perbuatan berdasarkan norma-norma Agama , hukum, tata krama, budaya, dan adat istiadat. ${ }^{30}$

Pendidikan karakter bertujuan untuk meningkatkan mutu penyelenggaraan dan hasil pendidikan di sekolah yang mengarah pada pencapaian pembentukan karakter dan akhlak mulia peserta didik secara utuh, terpadu, dan seimbang, sesuai standar kompetensi lulusan. Melalui pendidikan karakter diharapkan peserta didik mampu secara mandiri meningkatkan dan menggunakan pengetahuannya, mengkaji dan menginternalisasi serta mempersonalisasi nilai-nilai karakter dan akhlak mulia sehingga terwujud dalam perilaku sehari-hari.

Terminologi pendidikan karakter mulai dikenalkan sejak tahun 1900-an. Thomas Lickona dianggap sebagai pengusungnya, terutama ketika ia menulis buku yang berjudul The Return of Character Education dan kemudian disusul bukunya, Educating for Character: How Our School Can Teach Respect and Responsibility. Melalui buku buku itu, ia menyadarkan dunia Barat akan pentingnya pendidikan karakter. Pendidikan karakter menurut, Ryan dan Bohlin, mengandung tiga unsur pokok, yaitu mengetahui kebaikan (knowing the good), mencintai kebaikan (loving the good), dan melakukan kebaikan (doing the good). ${ }^{31}$

Pendidikan karakter tidak sekedar mengajarkan mana yang benar dan mana yang salah kepada anak.Tetapi lebih dari itu pendidikan karakter menanamkan kebiasaan (habituation) tentang yang baik sehingga siswa paham, mampu merasakan, dan mau melakukan yang baik. Pendidikan karakter membawa misi yang sama dengan pendidikan akhlak atau pendidikan moral.

Pembudayaan karakter (akhlak) mulia perlu dilakukan dan terwujudnya karakter (akhlak) mulia yang merupakan tujuan akhir dari suatu proses pendidikan sangat didambakan oleh setiap lembaga yang menyelenggarakan proses pendidikan. Budaya atau kultur yang ada di lembaga, baik sekolah, kampus, maupun yang lain, berperan penting dalam membangun akhlak mulia di kalangan sivitas akademika dan para karyawannya. Karena itu, lembaga pendidikan memiliki tugas dan tanggung jawab untuk melakukan pendidikan akhlak (pendidikan moral) bagi para peserta didik dan juga membangun kultur akhlak mulia bagi masyarakatnya.

${ }^{30}$ Abdul Majid dan Dian Andayani, Pendidikan Karakter Perspektif Islam, (Bandung, Rosda Karya, 2011), hlm. 16

${ }^{31}$ Ibid., hlm. 51 
Lebih luas lagi pendidikan karakter adalah suatu sistem penanaman nilai-nilai karakter kepada warga sekolah yang meliputi komponen pengetahuan, kesadaran atau kemauan, dan tindakan untuk melaksanakan nilai-nilai tersebut, baik terhadap Tuhan Yang Maha Esa (YME), diri sendiri, sesama, lingkungan, maupun kebangsaan sehingga menjadi manusia insan kamil. Dalam pendidikan karakter di sekolah, semua komponen (stakeholders) harus dilibatkan, termasuk komponen-komponen pendidikan itu sendiri, yaitu isi kurikulum, proses pembelajaran dan penilaian, kualitas hubungan, penanganan atau pengelolaan mata pelajaran, pengelolaan sekolah, pelaksanaan aktivitas atau kegiatan kokurikuler, pemberdayaan sarana prasarana, pembiayaan, dan ethos kerja seluruh warga dan lingkungan sekolah.

Pendidikan karakter pada tingkatan institusi mengarah pada pembentukan budaya sekolah, yaitu nilai-nilai yang melandasi perilaku, tradisi, kebiasaan keseharian, dan simbolsimbol yang dipraktikkan oleh semua warga sekolah, dan masyarakat sekitar sekolah. Budaya sekolah merupakan ciri khas, karakter atau watak, dan citra sekolah tersebut di mata masyarakat luas. ${ }^{32}$

Sasaran pendidikan karakter adalah seluruh sekolah di Indonesia negeri maupun swasta. Semua warga sekolah, meliputi para peserta didik, guru, karyawan administrasi, dan pimpinan sekolah menjadi sasaran program ini. Sekolah-sekolah yang selama ini telah berhasil melaksanakan pendidikan karakter dengan baik dijadikan sebagai best practices, yang menjadi contoh untuk disebarluaskan ke sekolah-sekolah lainnya.

Melalui program ini diharapkan lulusan memiliki keimanan dan ketaqwaan kepada Tuhan Yang Maha Esa, berakhlak mulia, berkarakter mulia, kompetensi akademik yang utuh dan terpadu, sekaligus memiliki kepribadian yang baik sesuai norma-norma dan budaya Indonesia. Pada tataran yang lebih luas, pendidikan karakter nantinya diharapkan menjadi budaya sekolah.

Dalam kaitan permasalahan pendidikan, pembangunan karakter dianggap sebagai solusi paling tepat untuk menjawab degradasi moral seperti yang terjadi saat ini. Selama ini pendidikan kita hanya menerapkan bagaimana target kurikulum terpenuhi dan lulus dengan angka yang tinggi. Hal ini disadari sebagai konsep yang keliru. Karena pendidikan ternyata bukan hanya teori tetapi jauh lebih penting dari itu adalah siswa mampu mempraktikan nilai-nilai dari ilmu yang didapat dalam kehidupan sehari-hari. ${ }^{33}$

Desain kurikulum pendidikan karakter bukan sebagai teks bahan ajar yang diajarkan secara akademik, tetapi lebih merupakan proses pembiasaan perilaku bermoral. Nilai moral dapat diajarkan secara tersendiri maupun diintegrasikan dengan seluruh mata pelajaran dengan mengangkat moral pendidikan atau moral kehidupan, sehingga seluruh proses

${ }^{32}$ Masnur Muslich, Pendidikan Karakter Menjawab Tantangan Krisis Multidimensional, (Jakarta, Bumi Aksara, 2011), hlm. 211

${ }^{33}$ Abd Majid dan Dian Andayani, Pendidikan...,2011, hlm. 79 
pendidikan merupakan proses moralisasi perilaku peserta didik. Bukan proses pemberian pengetahuan moral, tetapi suatu proses pengintegrasian moral pengetahuan.

Pendidikan karakter dipahami sebagai upaya menanamkan kecerdasan dalam berpikir, penghayatan dalam bentuk sikap, dan pengalaman dalam bentuk perilaku yang sesuai dengan nilai-nilai luhur yang menjadi jati dirinya. ${ }^{34}$ Penamaan pendidikan karakter tidak bisa hanya sekedar transfer ilmu pengetahuan atau melatih suatu keterampilan tertentu. Pendidikan karakter perlu proses, contoh teladan, pembiasaan atau pembudayaan dalam lingkungan peserta didik dalam lingkungan sekolah/madrasah, keluarga, lingkungan masyarakat, mapun lingkungan media masa.

Dari pengalaman ada dua pendekatan dalam pendidikan karakter, yaitu: (1) Karakter yangdiposisikan sebagai mata pelajaran tersendiri; dan (2) Karakter yang built- in dalam setiap mata pelajaran. Sampai saat ini, pendekatan pertama ternyata lebih efektif dibandingkan pendekatan kedua. Salah satu alasannya ialah karena para guru mengajarkan masih seputar teori dan konsep, belum sampai ke ranah metodologi dan aplikasinya dalam kehidupan. Idealnya, dalam setiap proses pembelajaran mencakup aspek konsep (hakekat), teori (syare'at), metode (tharekat) dan aplikasi (ma'rifat). Jika para guru sudah mengajarkan kurikulum secara komprehensif melalui konsep, teori, metodologi dan aplikasi setiap bidang studi, maka kebermaknaan yang diajarkannya akan lebih efektif dalam menunjang pendidikan karakter.

Nilai-nilai karakter antara lain: (1) Cinta kepada Allah dan alam semesta beserta isinya; (2) tanggung jawab, disiplin dan mandiri; (3) jujur; (4) hormat dan santun; (5) kasih sayang, peduli, dan kerja sama; (6) percaya diri, kreatif, kerja keras dan pantang menyerah; (7) keadilan dan kepemimpinan, baik dan rendah hati, dan toleransi, cinta damai, dan persatuan. Untuk implementasinya memerlukan kajian dan aplikasi nilai-nilai yang terkandung dalam karakter bangsa pada kegiatan pembelajaran di sekolah/madrasah. Integrasi nilai karakter bangsa pada kegiatan pembelajaran dapat dilakukan melalui tahap-tahap perencanaan, implementasi, dan evaluasi.

\section{Implementasi Pendidikan Karakter dalam Pembelajaran}

Untuk implementasinya memerlukan kajian dan aplikasi nilai-nilai yang terkandung dalam karakter bangsa pada kegiatan pembelajaran di sekolah/madrasah. Integrasi nilai karakter bangsa pada kegiatan pembelajaran dapat dilakukan melalui tahap-tahap perencanaan, implementasi, dan evaluasi.

Pendidikan karakter harus didasarkan pada prinsip-prinsip sebagai berikut:

1. Mempromosikan nilai-nilai dasar etika sebagai basis karakter

2. Mengidentifikasi karakter secara komprehensif mencakup pemikiran, perasaan, dan perilaku 
3. Menggunakan pendekatan yang tajam, proaktif dan efektif untuk membangun karakter

4. Menciptakan komunitas sekolah yang memiliki kepedulian

5. Memberi kesempatan kpeada peserta didik untuk menunjukkan perilaku yang baik

6. Memiliki cakupan terhadap kurikulum yang bermakna dan menantang yang menghargai semua peserta didik, membangun karakter mereka, dan membantu mereka untuk sukses

7. Mengusahakan tumbuhnya motivasi diri pada para peserta didik

8. Memfungsikan seluruh staf sekolah sebagai komunitas moral yang berbagi tanggung jawab untuk pendidikan karakter

9. Adanya pembagian kepemimpinan moral dan dukungan luas dalam membangun inisiatif pendidikan karakter

10. Memfungsikan keluarga dan anggota masyarakat sebagai mitra dalam usaha membangun karakter

11. Mengevaluasi karakter sekolah, fungsi staf sekolah sebagai guru-guru karakter, dan manifestasi karakter posisitf dalam kehidupan peserta didik.

Pengembangan karakter dalam suatu sistem pendidikan adalah keterkaitan antara komponen-komponen karakter yang mengandung nilai-nilai perilaku, yang dapat dilakukan atau bertindak secara bertahap dan saling berhubungan antara pengetahuan nilai-nilai perilaku dengan sikap atau emosi yang kuat untuk melaksanakannya, baik terhadap Tuhan YME, dirinya, sesama, lingkungan, bangsa dan negara serta dunia internasional (lihat Diagram 1).

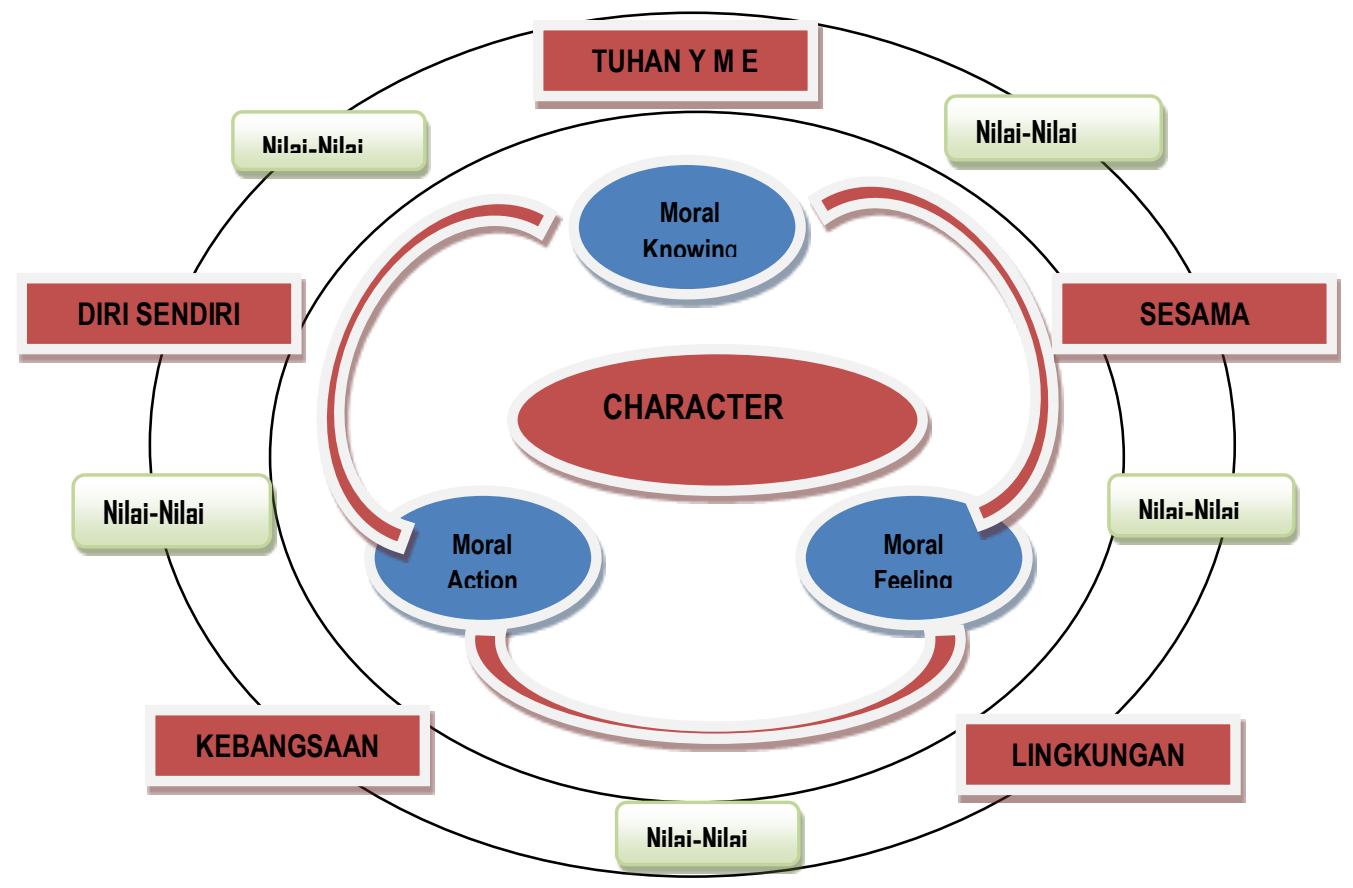

Diagram 1.

Keterkaitan komponen moral dalam pembentukan karakter 
Kebiasaan berbuat baik tidak selalu menjamin bahwa manusia yang telah terbiasa tersebut secara sadar menghargai pentingnya nilai karakter (valuing). Karena mungkin saja perbuatannya tersebut dilandasi oleh rasa takut untuk berbuat salah, bukan karena tingginya penghargaan akan nilai itu. Misalnya ketika seseorang berbuat jujur hal itu dilakukan karena dinilai oleh orang lain, bukan karena keinginannya yang tulus untuk mengharagi nilai kejujuran itu sendiri. Oleh karena itu dalam pendidikan karakter diperlukan juga aspek perasaan (domain affection atau emosi). Komponen ini dalam pendidikan karakter disebut dengan "desiring the good" atau keinginan untuk berbuat kebaikan.

Pendidikan karakter yang baik dengan demikian harus melibatkan bukan saja aspek "knowing the good" (moral knowing), tetapi juga "desiring the good" atau "loving the good" (moral feeling), dan "acting the good" (moral action). Tanpa itu semua manusia akan sama seperti robot yang terindoktrinasi oleh sesuatu paham. Dengan demikian jelas bahwa karakter dikembangkan melalui tiga langkah, yakni mengembangkan moral knowing, kemudian moral feeling, dan moral action. Dengan kata lain, makin lengkap komponen moral dimiliki manusia, maka akan makin membentuk karakter yang baik atau unggul/tangguh.

Proses pembelajaran pendidikan karakter secara terpadu bisa dibenarkan karena sejauh ini muncul keyakinan bahwa anak akan tumbuh dengan baik jika dilibatkan secara alamiah dalam proses belajar. Istilah terpadu dalam pembelajaran berarti pembelajaran menekankan pengalaman belajar dalam konteks yang bermakna. Pengajaran terpadu dapat didefinisikan: suatu konsep dapat dikatakan sebagai pendekatan belajar yang melibatkan beberapa bidang studi untuk memberikan pengalaman yang bermakna bagi peserta didik. Dikatakan bermakna karena dalam pembelajaran terpadu, peserta didik akan memahami konsep yang dipelajari melalui pengalam langsung dan menghubungkannya dengan konsep lain yang sudah dipahaminya melalui kesempatan mempelajari apa yang berhubungan dengan tema atau peristiwa autentik (alami).

Dengan demikian, ciri pendidikan terpadu adalah: (1) berpusat pada peserta didik; (2) memberikan pengalam langsung kepada peserta didik; (3) pemisahan bidang studi tidak begitu jelas; (4) menyajikan konsep dari berbagai bidang studi dalam suatu proses pembelajaran; (5) bersifat luwes, dan (6) hasil pembelajaran dapat berkembang sesuai dengan minat dan kebutuhan peserta didik. ${ }^{35}$

Integrasi pembelajaran dapat dilakukan dalam substansi materi, pendekatan, metode, dan model evaluasi yang dikembangkan. Tidak semua substansi materi pelajaran cocok untuk semua karakter yang akan dikembangkan, perlu dilakukan seleksi materi dan sinkronisasi dengan karakter yang akan dikembangkan. Pada prinsipnya semua mata pelajaran dapat digunakan sebagai alat untuk mengembangkan semua karakter

${ }^{35}$ Zubaidi, Desain...., hlm. 268 
peserta didik, namun agar tidak terjadi tumpang-tindih dan terabaikannya salah satu karakter yang akan dikembangkan, perlu dilakukan pemetaan berdasarkan kedekatan materi dengan karakter yang akan dikembangkan.

Dari segi pendekatan dan metode meliputi inkulkasi (inculcation), keteladanan (modeling,qudwah), fasilitasi (facilitation), dan pengembangan keterampilan (skill building). ${ }^{36}$ Inkulkasi (penanaman) nilai memiliki ciri-ciri: (1) mengomunikasikan kepercayaan disertai alasan yang mendasarinya; (2) memperlakukan orang lain secara adil; (3) menghargai pandangan orang lain; (4) mengemukakan keragu-raguan disertai alasan, dan dengan rasa hormat; (5) tidak sepenuhnya mengontrol lingkungan untuk meningkatkan kemungkinan penyampaian nilai-nilai yang dikehendaki; (6) menciptakan pengalaman sosial dan emosional mengenai nilai-nilai yang dikehendaki secara tidak ekstrem; (7) membuat aturan, memberikan penghargaan, dan memberikan konsekuensi disertai alasan; (8) tetap membuka komunikasi dengan pihak yang tidak setuju, dan (9) memberikan kebebasan bagi adanya perilaku yang berbeda-beda, apabila sampai pada tingkat yang tidak dapat diteriuma, diarahkan untuk memberikan kemungkinan berubah. Pendidikan karakter seharusnya tidak menggunakan metode induktrinasi yang memiliki ciri-ciri yang bertolak belakang dengan inkulkasi.

Dalam pendidikan karakter, pemodelan atau pemberian teladan merupakan strategi yang biasa digunakan. Untuk dapat menggunakan strategi ini ada dua syarat harus dipenuhi. Pertama, guru harus berperan sebagai model yang baik bagi peserta didik dan anaknya. Kedua, peserta didik harus meneladani orang terkenal yang berakhlak mulia, misalnya Nabi Muhammad saw. Cara guru menyelsaikan masalah dengan adil, menghargai pendapat anak dan mengeritik orang lain dengan santun, merupakan perilaku yang secara alami dijadikan model bagi anak.

Inkulkasi dan metode keteladanan (al-qudwah) mendemonstrasikan kepada peserta didik merupakan cara terbaik untuk mengatasi berbagai masalah; orang akan melakukan proses identifikasi, meniru, dan memeragakannya. Dengan metode pembiasaan, seseorang akan memiliki komitmen yang hebat. Pembiasaan dalam penanaman moral merupakan tahapan penting yang seyogianya menyertai perkembangan setiap mata pelajaran. Mengajari moral tanpa pembiasaan melakukannya, hanyalah menabur benih ke tengah lautan, karena moral bukan sekedar pengetahuan, tetapi pembiasaan bermoral. Fasilitasi melatih peserta didik mengatasi masalah-masalah tersebut. Kegiatan-kegiatan yang dilakukan peserta didik dalam melaksanakan metode fasilitasi membawa dampak positif pada perkembangn kepribadian peserta didik.

Pembelajaran moral bagi peserta didik akan lebih efektif apabila disajikan dalam bentuk gambar, seperti film, sehingga peserta didik bukan saja menangkap maknanya dari pesan verbal mono-pesan, melainkan bisa menangkap pesan yang multi-pesan dari gambar,

${ }^{36}$ Zuchdi, Humanisasi...., hlm. 46-50 
keterkaitan antargambar dan peristiwa dalam alur cerita yang disajikan. ${ }^{37}$ Contoh: penyampaian pesan bahwa narkoba itu harus dihindari, maka tayangan tentang derita orang-orang yang dipenjara karena korban narkoba jauh lebih bermakna daripada disampaikan secara lisan, melalui metode ceramah. Namun demikian, bila ingin lebih mendalam tingkat penerimaan mereka, bisa dilanjutkan dengan metode renungan (almuhasabah) setelah terkondisikan dengan baik melalui cerita dalam film yang baru saja ditayangkan.

Kecerdasan, keterampilan, dan ketangkasan seseorang berbeda-beda, sebagaimana perbedaan dalam temperamen dan wataknya. Ada yang memiliki temperamen tenang, mudah gugup atau grogi. Ada yang mudah paham dengan isyarat saja apabila salah dan ada yang tidak bisa berubah, kecuali setelah melihat mata membelalak, bahkan dengan bentakan, ancaman, dan hukuman secara fisik. Sekalipun hukuman pukulan merupakan salah satu metode dalam pendidikan, seyogianya guru tidak menggunakannya sebelum mencoba dulu dengan cara lain. Metode hukuman digunakan untuk menggugah serta mendidik perasaan rabbaniyah, yaitu perasaan khauf (takut) dan khusyu' ketika mengingat Allah dan membaca Al-Qur'an. ${ }^{38}$

Beberapa keterampilan yang diperlukan agar seseorang dapat mengamalkan nilai yang dianut sehingga berperilaku konstruktif dan bermoral dalam masyarakat. Keterampilan tersebut antara lain:

a. Keterampilan berpikir kritis, dengan ciri-ciri sebagai berikut: (1) mencari kejelasan pernyataan atau pertanyaan; (2) mencari alasan; (3) mencoba memperoleh informasi yang benar; (4) menggunakan sumber yang dapat dipercaya; (5) mempertimbangkan keseluruhan situasi; (6) mencari alternatif; (7) bersikap terbuka.

b. Keterampilan mengatasi masalah. Masih banyak orang mengatasi konflik dengan kekuatan fisik, padahal cara demikian itu biasa digunakan oleh binatang. Manusia yang menggunakan nilai religius dan prinsip moral dalam penyelesaian masalah kehidupan, perlu diajarkan cara mengatasinya yang konstruktif.

Perilaku moral (moral action) dapat dievaluasi secara akurat dengan melakukan observasi dalam jangka waktu relatif lama dan secara terus menerus. Pengamat atau pengobservasi harus orang yang sudah mengenal orang-orang yang diobservasi agar penafsirannya terhadap perilaku yang muncul tidak salah.

\footnotetext{
${ }^{37}$ Dalam dunia pendidikan, terutama yang berkaitan dengan pembelajaran, peran media pembelajaran begitu kuat. Albert Meharabien menemukan peran media dalam menyampaikan informasi, dengan rumus tiga $\mathrm{V}$. Verbal; hanya bisa menyampaikan 7\%, Vocal; bisa menyampaian 38\%, apabila disertai dengan warna suara yang variatif dan intonasi yang tepat, sedng visual; bisa mencapai angka keefektifan hingga 55\%. Manusia memiliki kemampuan lebih optimal untuk menangkap makna, melalui kesan yang bersifat visual dibandingkan yang verbal dan vocal. Baca Mursidin, Moral Sumber Pendidikan, Sebuah Formula Pendidikan Budi Pekerti di Sekolah/Madrasah, (Bogor: Ghalia Indonesia, 2011), hlm. 81-82

${ }^{38}$ Al-Nahlawi, Ushul al-Tarbiyah al-Islāmiyah wa Asālibuhā fi al-Bait wa al-Madrasah wa al-Mujtama', edisi ke25, (Damaskus: Dar al-Fikr, 2007), hlm. 232-233.Bandingkan Amin, Kitāb al-Akhlāq, (Cairo: Dar al-kutub alMishriyah, 1999), hlm. 3
} 
FITRAH Vol. 02 No. 1 Januari-Juni 2016

\section{PENUTUP}

Pendidikan yang hakiki merupakan ikhtiat untuk memperoleh nilai hidup, bukan nilai angka sebagaimana lazimnya saat ini, tetapi menghasilkan makna dari setiap pengetahuan yang dipelajarinya. Pemerolehan makna menjadi ukuran dari setiap proses pembelajaran. Tak ada proses belajar, bila belum menghasilkan rekonstruksi makna baru yang dapat memberikan pencerahan bagi si pembelajar.

Dunia pendidikan kita lebih sering menggunakan tes yang mengukur ranah pengetahuan ketimbang untuk mengukur ranah afektif. Soal-soal pada saat ulangan atau ujian nasional pun lebih banyak menuntut kemampuan kognitif daripada mengukur ranah afektif, akibatnya produk pendidikannya, output atau outcome, kurang memiliki moralitas yang baik. Tidak malu melakukan korupsi, tidak takut berbuat dosa dan kesalahan, serta tidak resah bila berbuat kezaliman.

Pendidikan karakter memerlukan metode khusus yang tepat agar tujuan pendidikan dapat tercapai. Di antara metode pembelajaran yang sesuai adalah metode keteladanan (alqudwah), metode pembiasaan, dan metode pujian dan hukuman.Dengan metode pembiasaan, seseorang akan memiliki komitmen yang hebat. Pembiasaan dalam penanaman moral merupakan tahapan penting yang seyogianya menyertai perkembangan setiap mata pelajaran. Mengajari moral tanpa pembiasaan melakukannya, hanyalah menabur benih ke tengah lautan, karena moral bukan sekedar pengetahuan, tetapi pembiasaan bermoral. 


\section{DAFTAR PUSTAKA}

Al-Abd, Muhammad. t.t., al-khlāq fi al-Islām, Cairo: al-Jami'ah al-Qahirah

Al-Nahlawi, 2007. Ushul al-Tarbiyah al-Islāmiyah wa Asālibuhā fi al-Bait wa al-Madrasah wa alMujtama', edisi ke-25, Damaskus: Dar al-Fikr

Amin, 1999. Kitāb al-Akhlāq, Cairo: Dar al-kutub al-Mishriyah

Zainal Arifin, 2012. Pengembangan Manajemen Mutu Kurikulum Pendidikan Islam, Jogjakarta: Diva Press

Jamal Asman Ma'mur. 2012. Buku Panduan Internalisasi Pendidikan Karakter di Sekolah, Jogjakarta: Diva Press

Abd. Assegaf Rachman. 2010. Pendidikan Islam Kontekstual, Yogyakarta: Pustaka Pelajar

A. Azizi, Qodri. 2003. Pendidikan Untuk Membangun Etika Sosial, Semarang: Aneka Ilmu

Sudarwan Danim, 2003. Agenda Pembaruan Sistem Pendidikan. Yogyakarta: Pustaka Pelajar

Darmaningtyas, 2011. Pendidikan Rusak-Rusakan, Yogyakarta: LKiS

Heri Gunawan, 2012. Pendidikan Karakter Konsep Dan Implementasi, Bandung: Alfabeta

Hadjar, 2010. Evaluasi Hasil Belajar Afektif Pendidikan Agama: Konsep dan Pengukurannya, Muntholi'ah (ed.), Guru Besar Bicara Mengembangkan Keilmuan Pendidikan Islam,Semarang: Fakultas Tarbiyah IAIN Walisanga dan RaSAIL Media Group

Andri Hakim, 2010. Hypnosis in Teaching, Jakarta Selatan: Transmedia Pustaka

Hamalik,Oemar. 2007.Manajemen Pengembangan Kurikulum, Bandung: Rosdakarya

Hidayatullah, M. Furqon. 2010. Pendidikan Karakter: Membangun Peradaban Bangsa, Surakarta: Yuma Pustaka

Husaini, Ardian. 2010. Pendidikan Islam: Membentuk Manusia Berkarakter dan Beradab, Jakarta: Cakrawala Publishing

Idi, Abdullah.2007. Pengembangan kurikulum; Teori dan Praktik, Yogyakarta: Ar Ruzz Media

Irianto, Agus. 2011. Pendidikan Sebagai Investasi Dalam Pembangunan Bangsa, Jakarta: Kencana Prenada Media

Kesuma, Dharma, dkk. 2011. Pendidikan Karakter Kajian Teori dan Praktik di Sekolah, Bandung: PT. Rosda Karya.

Koesoema, Doni. 2011. Pendidikan Karakter Setrategi Mendidik Anak di Zaman Global, Jakarta: Grasindo

Lickona, Thomas. 1991.Educating for Character: How Our School Can Teach Respect and Responsibility. New York, Toronto, London, Sydney, Aucland: Bantam books

Lie, Anita. 2002. Cooperative Learning: Mempraktikkan Cooperative Learning di RuangRuangKelas. Jakarta: Grasindo,

Majid, Abdul dan Dian Andayani. 2011. Pendidikan Karakter Perspektif Islam, Bandung: Remaja Rosda Karya

Muhaimin, dkk, 2008. Paradigma Pendidikan Islam, Bandung: Rosda Karya 
FITRAH Vol. 02 No. 1 Januari - Juni 2016

Mursidin, 2011. Moral Sumber Pendidikan, Sebuah Formula Pendidikan Budi Pekerti di Sekolah/Madrasah, Bogor: Ghalia Indonesia

Muslich, Masnur. 2011. Pendidikan Karakter Menjawab Tantangan Krisis Multidimensional, Jakarta: Bumi Aksara

Narwanti, Sri. 2011. Pendidikan Karakter Pengintegrasian 18 Nilai Pembentuk Karakter dalam Mata Pelajaran, Yogyakarta: Familia

Rosyada, Dede. 2004. Paradigma Pendidikan Demokratis: Sebuah Model Pelibatan Masyarakat dalam Penyelenggaraan Pendidikan. Jakarta: Kencana

S. Nasution, 2003. Pengembangan Kurikulum, Bandung: Citra Aditya Bakti

Sagala,Syaiful. 2009.Pendidikan Kontemporer, Jakarta: Alfabeta

Sanjaya, 2010.Kurikulum dan Pembelajaran, Jakarta: Kencana Prenda Media Group,

Sardar, Ziauddin. 2000. Merombak Pola Pikir Intelektual Muslim. (terj) Agung Prihantoro dan Fuad Arif Fudyartanto. Yogyakarta: Pustaka Pelajar

Tim Redaksi Tessaurus Bahasa Indonesia. 2008. Tesaurus Bahasa Indonesia Pusat Bahasa. Jakarta: Departemen Pendidikan Nasional

Widiastono, Tony D. (ed). 2004. Pendidikan Manusia Indonesia.Jakarta: Buku Kompas.

Zubaidi, 2011. Desain Pendidikan Karakter, Jakarta: Prenada Media Group

Zuchdi, 2009. Humanisasi Pendidikan, Jakarta: PT Bumi Aksara 